\title{
A Review on Biomaterials for 3D Conductive Scaffolds for Stimulating and Monitoring Cellular Activities
}

\author{
Muhammad Ahmed Khan *, Edoardo Cantù, Sarah Tonello®), Mauro Serpelloni®), \\ Nicola Francesco Lopomo $(\mathbb{D})$ and Emilio Sardini $(\mathbb{D})$ \\ Department of Information Engineering, University of Brescia, Via Branze 38, 25123 Brescia, Italy; \\ e.cantu@unibs.it (E.C.); s.tonello@unibs.it (S.T.); mauro.serpelloni@unibs.it (M.S.); \\ nicola.lopomo@unibs.it (N.F.L.); emilio.sardini@unibs.it (E.S.) \\ * Correspondence: m.khan004@unibs.it
}

Received: 15 February 2019; Accepted: 28 February 2019; Published: 7 March 2019

\begin{abstract}
During the last years, scientific research in biotechnology has been reporting a considerable boost forward due to many advances marked in different technological areas. Researchers working in the field of regenerative medicine, mechanobiology and pharmacology have been constantly looking for non-invasive methods able to track tissue development, monitor biological processes and check effectiveness in treatments. The possibility to control cell cultures and quantify their products represents indeed one of the most promising and exciting hurdles. In this perspective, the use of conductive materials able to map cell activity in a three-dimensional environment represents the most interesting approach. The greatest potential of this strategy relies on the possibility to correlate measurable changes in electrical parameters with specific cell cycle events, without affecting their maturation process and considering a physiological-like setting. Up to now, several conductive materials has been identified and validated as possible solutions in scaffold development, but still few works have stressed the possibility to use conductive scaffolds for non-invasive electrical cell monitoring. In this picture, the main objective of this review was to define the state-of-the-art concerning conductive biomaterials to provide researchers with practical guidelines for developing specific applications addressing cell growth and differentiation monitoring. Therefore, a comprehensive review of all the available conductive biomaterials (polymers, carbon-based, and metals) was given in terms of their main electric characteristics and range of applications.
\end{abstract}

Keywords: conductive scaffolds; cell culture monitoring; impedance-based monitoring; non-invasive monitoring

\section{Introduction}

Scaffold-based 3D cell cultures are highly investigated for many applications in pharmacology, drug development, diagnostics, tissue engineering, and regenerative medicine. Their main value relies on the capability to reproduce an environment which mimics the in vivo conditions actually undergone by cells. This approach improves reliability and usefulness of the results obtained in in vitro experiments-in terms of cell response to drugs, nanomaterials and biomolecules-addressing the translation to in vivo applications [1].

Nowadays, traditional analytical evaluations, considered the reliable "gold standard", are performed by using dyes, DNA sequencing, immune-based assays, or fluorescence tags, which are often invasive, sample destructive and therefore prevent continuous monitoring. In this picture, one of the most critical hurdle is the possibility to evaluate specific cell functions without affecting their 
developmental processes. This would ensure a fundamental leap towards an improved and interactive monitoring of cell cultures [2,3].

Several efforts have been performed starting from 1970 to implement non-invasive strategies for monitoring cells and interacting with them by means of different physical cues (e.g., optical, electrical, or magnetic) [4]. Among all, specific techniques based on the application of an electrical field are attractive in terms of non-invasiveness, accuracy, sensitivity, low-cost, and time effectiveness. In this light, researchers started to investigate several methods to interact with cell development by recording or stimulating them by using specific electrical signals [5].

Electrical-based techniques for cell monitoring can be mainly classified in potential- and impedance-based ones. The first one-applicable to electrically active cells-usually gives the possibility to record/stimulate cell growth by means of a planar array of micrometric metallic electrode [6]. The latter one, suitable for monitoring also non-electrically active cells, relates cell behavior to measurable changes of the electric impedance, due to their inherent structure and morphology [7]. Throughout the years, both these techniques have become widespread methods for pharmacological drug development, biomarkers screening and in vitro pathology modeling [8-14].

In the last decades, a huge interest has been addressed toward to possibility to translate both these techniques from $2 \mathrm{D}$ to $3 \mathrm{D}$ sensing $[15,16]$. This further methodological exploitation may ensure the monitoring of cells growth or differentiation with improved reliability, for both pharmacology and regenerative medicine purposes.

The main issues introduced when shifting this approach towards 3D environment are related with the distance between cells and electrodes and the electrical properties of the scaffold materials, both of which might affect the overall reliability in the measurements.

Regarding a potential-based approach, the contact between electrodes and cells is considered primarily necessary in order to get a proper interaction both during recording and stimulating phases. By using a traditional 3D structure with non-conducting material, the contact between cells and microelectrodes is certainly impaired by the presence of the scaffold itself. Thus, the possibility to improve the overall conductivity of the scaffold is of primary interest [17-19].

Regarding impedance-based solutions, when switching from 2D to 3D environment, the main issue is represented by the electrical properties of the material used to embed and sustain cell growth, which has a predominant role in the measurement of the overall system (i.e., cells + scaffold) impedance [20]. The introduction of conductive materials-as alternative or combined with the traditional polymer/natural non-conductive matrices-thus represents a promising strategy to improve the interaction between sensors and cells and avoid the need of external invasive device [21,22]. However, it is mandatory to properly tune the electric characteristics of the scaffold in order to be sensitive at all the changes in impedance due to cell adhesion, growth, and differentiation [23,24].

Considering these main concerns, the identification of the correct biomaterial, in terms of electric characteristics and manufacturing properties, represent the main variable for obtaining an effective system able to monitor 3D cell cultures. Conductivity, combined with proper biocompatibility and mechanical strength, has been highly investigated as possible cue for improving the performances of engineered tissues, but also to positively influence cell growth and differentiation [22]. Thus, the use of biocompatible conductive polymers or additive materials/nanomaterials could ensure the possibility to create a favorable culture environment to simultaneously promote cellular activities and assist cell monitoring. In this picture, this review aimed to give a systematic analysis of the current state-of-the art concerning the use of biomaterials in 3D cell culture monitoring. After separately introducing conductive polymers, carbon-based, and metallic materials, an overall discussion is performed comparing the identified solutions in term of electrical performances and biocompatibility. In addition, critical considerations are performed regarding the possibility to tune well the properties depending on the cell types and regarding the specific measurement strategies, thus to provide some preliminary guidelines to achieve non-invasive solutions for 3D cell monitoring. 


\section{Materials and Methods}

In order to perform this systematic review, specific keywords were considered in the searching strategy, thus to select the most relevant papers then described in each section. The review strategy included an extended bibliographic search on Scopus and PubMed online databases and including references on published manuscripts. No year restriction was used. The search terms were "scaffold production techniques", "conductive scaffolds", "conductive polymers" and "impedance based cell monitoring". Studies were included in the analysis, if they met all the following criteria:

- the study was a scientific article written in English;

- the study was focused on the use of conductive biomaterials for cell monitoring;

- the study reported information about the choice of the used materials, their properties and the manufacturing process.

All the papers were first selected according to the title; after that, the abstracts were examined in order to exclude those studies that were irrelevant for this analysis.

\section{Results}

The literature search identified 250 potentially relevant studies. After revisiting the titles and abstracts, the reviewers recognized 150 possible studies to be included in the systematic review. Finally, 122 unique studies were available.

Since the overall aim of the review was to give a comprehensive view of all the most updated strategies available to perform cell monitoring in 3D environment, analysis and discussion of the identified papers was divided in two different sections: the first one focused on conductive polymers, whereas the second one on carbon- and metal-based solutions including additive/fillers and nanomaterials. Each section specifically reported information on each identified material and finally, an overall comparison exploiting the advantages and disadvantages of using each material was performed and discussed, in order to point out suggestion for future improvement in this specific research area.

\subsection{Conductive Polymers}

Conductive polymers (CPs) and their derivatives are commonly used in biomedical engineering and have gained much importance in the last 20 years, because they exhibit chemical and physical characteristics of organic polymers along with electrical properties of metals [25]. Conductive polymers provide electrical stimulus and a physical environment for tissue genesis, cell growth and allow precise control over the duration and level of stimulation [26]. Researches showed that they are widely used in biological applications and they have the capability to modulate and support the growth of various cells including bone cells and nerve cells [27]. In addition, conductive polymers are also used to design polymeric composites with enhanced structural, mechanical and electrical properties and hence proved to be helpful in regenerative medicine including cardiac and neural tissue engineering [28]. CPs mainly used in biomedical area are polypyrrole (PPy), polyaniline (PANI), and polythiophene (PEDOT), with their electrical and optical properties [29-32]. Hereinafter, several details for each type of material.

- Polypyrrole (PPy)—PPy is conductive conjugated polymer with excellent mechanical, electrical and stimulus-responsive characteristics, which makes it one of the most conductive biomaterials, appropriate to be used in biomedicine [33]. Polypyrrole possesses great chemical stability in water and air [34,35], and high electrical conductivity under biological conditions [36-39]. It can be synthesized with various different porosities and can be adjusted to make it more feasible for biomedical applications by incorporating with bioactive molecules [40-42]. Moreover, its stimulus responsive nature allows to control its properties by applying electrical potential $[39,43]$. As a 
biomaterial, PPy also supports cell growth and adhesion of a number of different types of cell, which makes it a suitable for scaffold fabrication in tissue engineering [44-47].

- Polyaniline (PANI)—The second most studied conductive polymer is polyaniline (PANI) which is commonly known as aniline black. It is classified into three types depending on its oxidation level, such as the fully oxidized form is pernigraniline base, half-oxidized form is emeraldine base and fully reduced form is leucoemeraldine base. Among these, most conductive and stable is PANI emaraldine $[48,49]$. PANI offers many advantages over other conducting polymers, such as low-cost, easy to synthesize, and able to electrically switch between its resistive and conductive states [50-54]. Studies have shown that PANI and its derivative support cell growth [55] and hence can be used for scaffold fabrication.

- Poly (3,4-ethylenedioxythiophene) (PEDOT)—Another conductive polymer is PEDOT which is a polythiophene (PTh) derivative $[48,56]$. PEDOT possesses good electrical, environmental and chemical stability [56]. It also have better thermal stability and conductivity than PPy $[49,56]$. Luo et al. (2008) [57] carried out an in vivo study and examined the biocompatibility of PEDOT by seeding NIH3T3 fibroblasts cells on PEDOT based films. The results showed good inflammatory response at the implantation site with low intrinsic cytotoxicity, hence making them suitable for biological and biosensing applications e.g., in neural electrodes $[49,56,58]$, heart muscle patches, and nerve grafts [56].

A summary of the specific properties of each material are reported in Table 1.

By using these polymers is possible to produce conductive scaffolds, with the aim of defining platforms for cell sensing. The cell growth and colonization of the scaffold brings changes in its electrochemical impedance [59] and this change can be used to track cell growth. In [60], knowing that the PEDOT:xanthan gum scaffolds can efficiently facilitate cell culture, the electrical properties has been investigated by means of electrochemical impedance spectroscopy (EIS) and studied their evolution during cell growth as a tool to monitor cell growth. In [60], the PEDOT:xanthan gum scaffold is combined with electrode based device and there overall experimental setup has been reported in Figure 1. Specifically, gold electrodes were patterned on top of glass substrates, while a polydimethylsiloxane (PDMS) "well" was used to confine the scaffolds inside the electrode area. The $\mathrm{Ag} / \mathrm{AgCl} / \mathrm{KCl}(3 \mathrm{M})$ reference electrode and platinum $(\mathrm{Pt})$ mesh counter electrode were immobilized inside the wells. The impedance data (presented as Bode plot) revealed a significant increase in the impedance value that was modeled as additional capacitance elements in the equivalent circuit, which corresponds to the growth of insulating cell layers in the pores of the scaffold [61]. A less pronounced change can be observed for mid to high frequencies, with a slight increase in the impedance values most likely associated with the presence of cells contributing to the increase of the Ohmic resistance at the working electrode-electrolyte interface.

Table 1. Properties of different conductive polymers and corresponding techniques used in manufacturing scaffolds.

\begin{tabular}{cccc}
\hline Conductive Polymers & Manufacturing Techniques & Conductivity (Scm ${ }^{-\mathbf{1}}$ ) & References \\
\hline PPy or PPy & $\begin{array}{c}\text { Electrospinning, freeze drying, } \\
\text { in situ polymerization }\end{array}$ & $10^{2}-7.5 \times 10^{3}$ & {$[62-68]$} \\
PAN or PAN & Electrospinning & $30-200$ & {$[62,69,70]$} \\
PEDOT or PEDOT & $\begin{array}{c}\text { Freeze drying, vapor-phase } \\
\text { polymerization, solvent casting }\end{array}$ & $10-10^{3}$ & {$[60,62,71,72]$} \\
\hline
\end{tabular}


a)

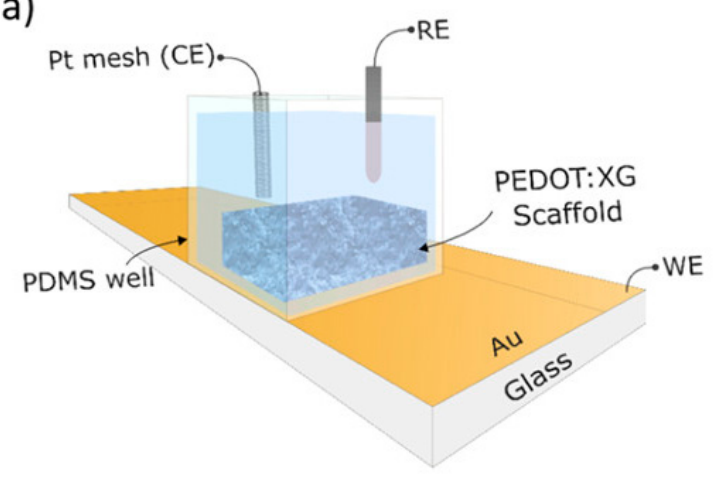

b)
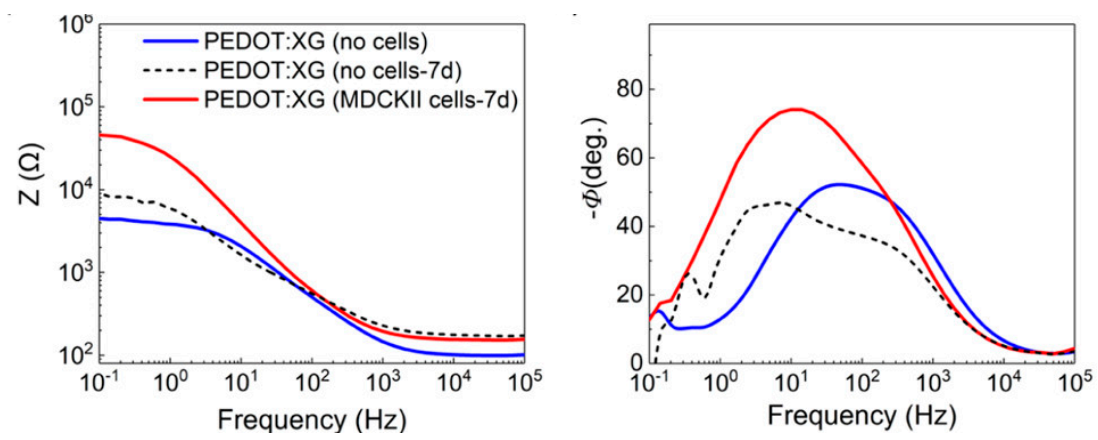

Figure 1. (a) Experimental setup for electrode-based device with scaffold; (b) impedance magnitude and phase shift change with and without cells (reprinted with copyright permission [60] Copyright (C) 2018 American Chemical Society).

\subsection{Conductive Fillers}

A different method to design and produce conductive scaffolds is to work within their inherent structure; in general an optimal approach is to add conductive filler in non-conductive polymer, such as gelatin, chitosan, PLLA (polyl-L-lactide acid), PCL (poly-caprolactone), and PLGA (poly(lactic-coglycolic acid)). Following these guidelines, the literature reported two different types of approaches, including carbon- and metal-based fillers and nanostructures.

\subsubsection{Carbon-Based Solutions}

Mainly, carbon-based fillers such as carbon black, graphene, carbon nanofibers and carbon nanotubes are widely used to increase conductivity $[73,74]$.

- Carbon Black-Carbon black fillers are preferred over metal fillers as they do not undergo oxidation, whereas, metal fillers get oxidized and create an insulation layer on particles surface [75]. Other advantages of hybrid composites made from carbon black fillers include: flexibility, light weight process capabilities, absorption of mechanical shock, and low production costs [76]. In [77], carbon black nanoparticles have been used to develop an electric responsive scaffold for cardiomyocytes-related experiments, showing good adhesion and viability.

- Carbon Nanotubes - Carbon nanotubes (CNTs) possess extremely high strength together with low density and high electrical conductivity. CNTs are widely used in scaffold-related applications, as they support cell adhesion and their dimensions are comparable with extracellular matrix (ECM) molecules [78]. In [79,80], CNTs are used as carbon filler showing that these fillers has remarkably increased the conductivity and mechanical strength of designed scaffolds. A 3D-structure with tunable porosity for cardiac tissue engineering was developed, showing reinforced properties in terms of mechanical and electrical properties thanks to DWCNTs [81]. Also nerve tissue 
engineering applications, regarding both central nervous system (CNS) and peripheral nervous system (PNS), were studied in presence of CNTs showing cells proliferation and viability $[78,82]$.

- Carbon Fibers and Nanofibers - Carbon nanofibers (CNFs) could mechanically strengthen scaffolds and have the availability of higher amount of sites on the outer wall respect CNTs, thus facilitating electron transfer for electroactive analytes such as proteins and enzymes [83]. In [83], CNFs were successfully used in a chitosan matrix to fabricate an electrically conductive scaffold with a highly porous and interconnected structure for cardiac tissue engineering exhibiting high electrical properties and an elastic modulus similar to that of rat myocardium. CNFs were also incorporated in a biocompatible scaffold made up of cotton, which was carbonized, oxidized, and coated with polydopamine (PDA) to study nerve cells proliferation and differentiation, obtaining a final material similar to native cellular physiological environment facilitating cell adhesion, proliferation, differentiation, and other biofunctions [84].

- Graphene-Graphene is a single layer of carbon atoms in a hexagonal lattice, capable of high mechanical properties combined with high electrical conductivity and biocompatibility. Graphene showed an important versatility since it was employed as filler in different base materials like chitosan/gelatin matrices, hydrogels and Poly(trimethylene carbonate) (PTMC). Biological properties like better adhesion, spreading and proliferation of cells on the conductive graphene make it a suitable material for scaffold based applications in tissue engineering [85-91].

A summary of the specific properties of each carbon-based filler are reported in Table 2.

Table 2. Properties of different carbon-based fillers and corresponding techniques used in manufacturing scaffolds.

\begin{tabular}{|c|c|c|c|}
\hline Fillers & Manufacturing Techniques & Conductivity $\left(\mathrm{Scm}^{-1}\right)$ & References \\
\hline Carbon black nanofillers & $\begin{array}{l}\text { Reversible esterification reaction and two } \\
\text { crosslinking steps }\end{array}$ & / & {$[77]$} \\
\hline $\begin{array}{l}\text { Carbon fibers and } \\
\text { nano fibers }\end{array}$ & $\begin{array}{l}\text { Precipitation, Heat treatment + surface } \\
\text { oxidization + PDA coating }\end{array}$ & $4 \times 10^{-4}-128,2 \times 10^{-2}$ & {$[83,84]$} \\
\hline CNTs & $\begin{array}{l}\text { Electrospinning, chemical vapor deposition } \\
\text { and oxidative purification; } \\
\text { Pressure-Activated Microsyringe (PAM); } \\
\text { High pressure carbon monoxide conversion } \\
\text { synthesis and suspension mixing. }\end{array}$ & $1 \times 10^{-9}-3.72 \times 10^{2}$ & {$[78,81,82]$} \\
\hline Graphene & $\begin{array}{l}\text { Electrospinning and hydrazine vapors; } \\
\text { co-electrospinning; Electrospinning and 3D } \\
\text { ultrasound expansion; Emulsion } \\
\text { polymerization by chemical oxidation } \\
\text { method; Bioplotter extrusion printing with } \\
\text { UV cross-linking }\end{array}$ & $0.93 \times 10^{-7}-2.52$ & {$[85-91]$} \\
\hline
\end{tabular}

In [78], CNTs/PLLA sensing scaffolds were microfabricated using Pressure-Activated Microsyringes (PAMs), a rapid prototyping microfabrication system which extrudes polymer solutions for biomedical and biosensing applications. Studies were carried out in presence of hepatocytes C3A cells and an electric cell-substrate impedance sensing (ECIS) method has been used, in which the impedance change of scaffold is recorded and correlated with corresponding cellular activities. The experimental results show that the impedance changes by approximately $40 \%$ in presence of cells and hence can be correlated with spreading, adhesion and changes in cell density (Figure 2). Thus, in this research, no electrodes were used and instead a smart scaffold was designed, which behaves as a biosensor for evaluating cell behavior (cell adhesion, proliferation) along with directing cellular growth. 

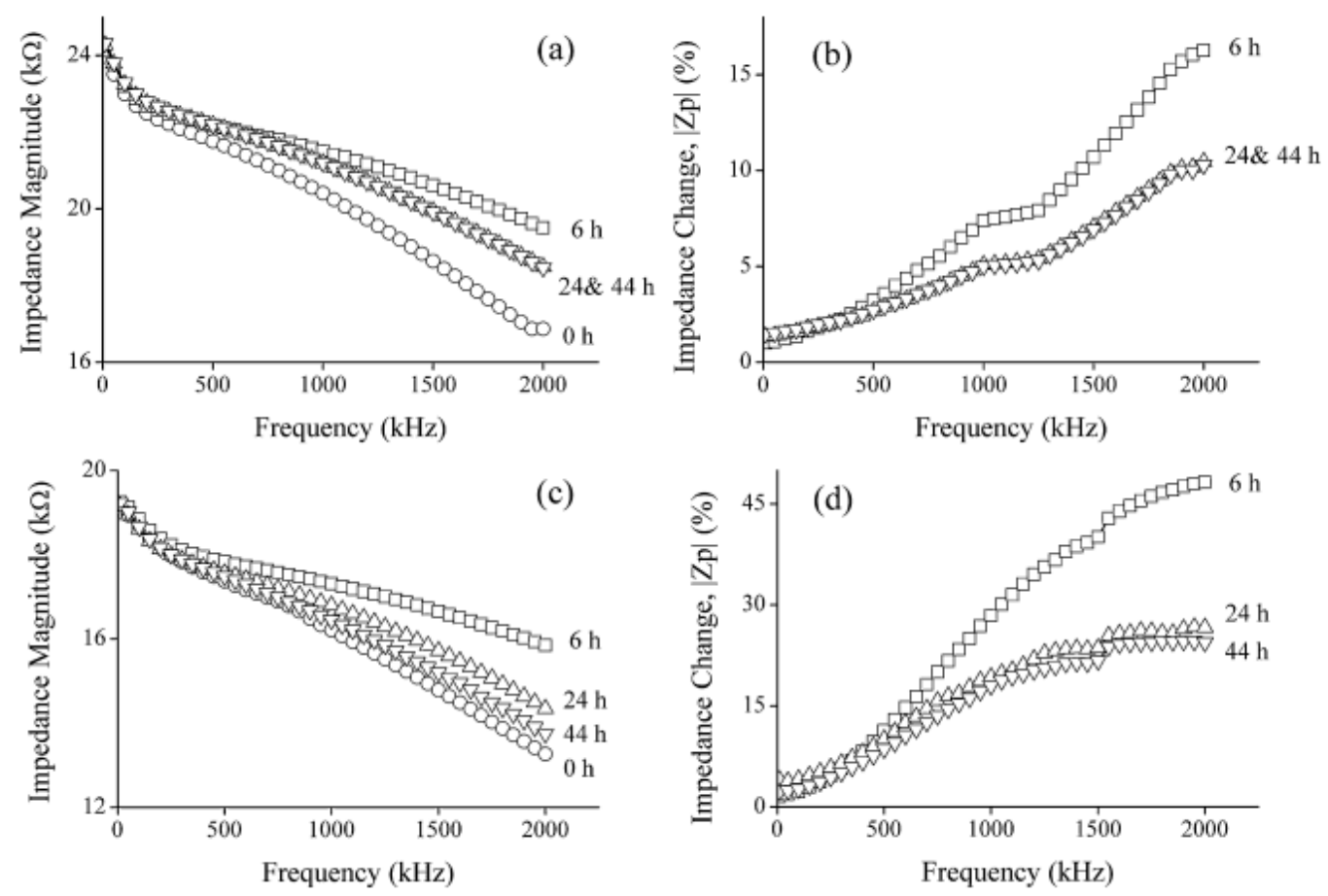

Figure 2. (a) Impedance spectrum (real part) of a typical membrane coated with collagen and immersed in medium at $0,6,24$, and $44 \mathrm{~h}$. Note that the 24 and $44 \mathrm{~h}$ spectra are coincident. (b) Impedance magnitude change, $|\mathrm{Zp}|$, for the same membrane with respect to time $0 \mathrm{~h}$. (c) Plot of real impedance values for a CNT/PLLA membrane with C3A cells as a function of time after cell seeding, (d) magnitude of impedance change for the same membrane. (Reprinted with copyright permission [78] Copyright (C) 2011 Elsevier).

\subsubsection{Metal-Based Solutions}

The metal-based solutions are mainly founded on the use of noble metals, which are resistant to corrosion and oxidation in moist air [73,74].

- Gold-An interesting metal which has attracted attention in fields ranging from drug delivery, cancer therapies and regenerative medicine is gold, specifically gold nanoparticles (AuNPs). Gold is noble metal characterized by fundamental properties for tissue engineering like: biocompatibility, electrical, optical and catalytic properties, ease of functionalization, higher mechanical properties. It has been proven that AuNPs are capable to enhance intercellular electrical communications, augment cardiomyocyte function and cardiac differentiation of MSC. They have been used to produce a unique extracellular milieu that couples tunable conductivity and elasticity for cardiac tissue engineering (CTE) [92-94]. AuNPs have been employed together with different polymers to obtain conductive scaffolds evidencing an outgrowth process, where neurites originate from the soma, extend and branch, developing into a complex dendritic tree [95].

- Platinum-Platinum Nanoparticles (PtNPs) have been indicated as promising biocompatible metal, which, when incorporated within scaffold, produce a positive influence both on cell growth and conductivity of the overall scaffold; thus, ensuring the possibility of an electric-based monitoring of cellular activities. Additionally, they protect cells from oxidation-induced inflammation which inhibits pulmonary inflammation and induced bone loss by decreasing osteoclastogenesis. PtNPs also assisted cell growth and could promote cell proliferation [96]. 
- Silver-Silver (Ag) is a well-known material already used in coatings for biomedical devices and in wound care products thanks to its antibacterial properties. Since it is a metal, it shows electrical conductivity and charge storage capacity $[97,98]$. It must be underlined that this metal is under debate regarding the aspect of biocompatibility: Ag antibacterial properties are associated to the release of $\mathrm{Ag}^{+}$ions and their release rate can be affected by silver nanoparticles (AgNPs) surface to volume ratio and capping agents, thus leading in toxicity problems [98].

- Zinc-Complex tissue regeneration of peripheral nervous system (PNS) and, particularly central nervous system (CNS) (no spontaneous regeneration due to inhibitory cues connected to astroglial cells) suggest the usage of nanoparticles due to their ability to reduce activity of undesirable cells. In order to enhance neural tissue regeneration in electrical fields through conductive materials, like piezoelectric materials, zinc is a promising candidate in this field. This metal presents important properties like biodegradability (lower degradation rate than iron and magnesium (0.018-0.145 mm/year)), biocompatibility, suturability, non-toxic behavior and rapid healing capacity $[99,100]$.

The main characteristics of metal-based fillers and the corresponding manufacturing techniques used in developing scaffolds, are reported in Table 3.

Table 3. Properties of different metal-based fillers and corresponding techniques used in manufacturing scaffolds.

\begin{tabular}{cccc}
\hline Fillers & Manufacturing Techniques & Conductivity $\left(\mathbf{S c m}^{\mathbf{- 1}}\right)$ & References \\
\hline Gold nanofillers & $\begin{array}{c}\text { Electrospinning, capillary force lithography } \\
\text { + electron beam evaporation }\end{array}$ & $10^{-4}-2 \times 10^{5}$ & {$[92-95]$} \\
Silver nanofillers & Capillary force lithography + electron beam & 4 & {$[97,98]$} \\
Platinum nanofillers & evaporation & $/$ & {$[96]$} \\
Zinc nanofillers & Heat sintering & $0.01-0.08$ & {$[99,100]$} \\
\hline
\end{tabular}

\section{Discussion}

The performed review aimed at systematically analyze the current state-of-the-art related to conductive materials usable for tissue engineering purposes, i.e., sensing and stimulating supports such as scaffolds. In this perspective, it is fundamental not only underline the types of materials available, but it is also mandatory to stress out the main specific applications. For this reason, the discussion section is addressed towards the identification of the most promising application thus to discuss the practical advantages and disadvantages of each conductive biomaterial. Furthermore, this approach might give useful guidelines to researchers for future implementations of conductive biomaterials for scaffolds development. As summarized in Table 4, three most relevant fields of applications were highlighted in the literature: neural, cardiac and bone tissue engineering.

Applications of conductive biomaterials encompassing the use of electroactive cells (neurons and myocytes) require the use of biomaterials that could interact with the cells ensuring both monitoring and stimulation. In order to ensure this interaction, high electrical conductivity in biological environment, high thermal and electrical stability and tunable electrical properties represent fundamental and mandatory key requirements. 
Table 4. Properties of different metal-based fillers and corresponding techniques used in manufacturing scaffolds.

\begin{tabular}{|c|c|c|c|}
\hline Application Areas & Conductive Material & Effect on Cellular Activities & References \\
\hline \multirow{8}{*}{$\begin{array}{l}\text { Neural Tissue } \\
\text { Engineering }\end{array}$} & $\begin{array}{l}\text { PPy: } \\
\text { i. PPy/PLA } \\
\text { ii. PPy/PLGA } \\
\text { iii. PPy/PCLF }\end{array}$ & $\begin{array}{l}\text { An increased c-Fos gene expression level and enhanced } \\
\text { nerve regeneration } \\
\text { Formation of longer neurites by electrical stimulation of } \\
\text { PC12 cells } \\
\text { Enhancing the PC12 cell attachment. }\end{array}$ & [101-104] \\
\hline & $\begin{array}{l}\text { PEDOT: } \\
\text { i. PEDOT/agarose gel hydrogel } \\
\text { ii. PEDOT/HA/PLA }\end{array}$ & $\begin{array}{l}\text { Development of nerve conduits for axonal regeneration. } \\
\text { Electrical stimulation of PC12 cells for neural } \\
\text { out growth. }\end{array}$ & {$[105,106]$} \\
\hline & $\begin{array}{l}\text { Carbon fibers and nanofibers: } \\
\text { Cotton/CNFs/Poly-dopamine (PDA) }\end{array}$ & $\begin{array}{l}\text { Electrical stimulation accelerated cell proliferation and } \\
\text { differentiation of nerve cells }\end{array}$ & [84] \\
\hline & $\begin{array}{l}\text { CNTs: } \\
\text { Hydrogel containing single-walled carbon } \\
\text { nanotubes (SWCNTs) }\end{array}$ & $\begin{array}{l}\text { Schwann cell (SC) response to SWCNT is examined in } \\
\text { both } 2 \mathrm{D} \text { and } 3 \mathrm{D} \text { microenvironments }\end{array}$ & [82] \\
\hline & $\begin{array}{l}\text { Graphene: } \\
\text { i. Conductive polyaniline/graphene (PAG) } \\
\text { nanoparticles into a chitosan/gelatin matrix } \\
\text { ii. Polyaniline/graphene } \\
\text { (PAG) nanocomposites }\end{array}$ & $\begin{array}{l}\text { Electrical and mechanical properties increased } \\
\text { depending on the PAG content } \\
\text { Improved electrical conductivity, stabilized } \\
\text { thermal behavior }\end{array}$ & {$[85,90]$} \\
\hline & $\begin{array}{l}\text { Au: } \\
\text { polycaprolactone (PCL)-gelatin }\end{array}$ & $\begin{array}{l}\text { Enhances neuronal proliferation with encouraged axonal } \\
\text { elongation over forming a complex branching trees }\end{array}$ & [95] \\
\hline & $\begin{array}{l}\text { Ag: } \\
\text { Carboxylated Cellulose } \\
\text { Nanofibers-Dopamine/Silver Nanoparticles } \\
\text { (CCNF-DA/AgNPs) }\end{array}$ & $\begin{array}{l}\text { Improved mechanical properties, antimicrobial activity } \\
\text { (Gram-positive and Gram-negative bacteria), } \\
\text { and electrical conductivity }\end{array}$ & [97] \\
\hline & $\begin{array}{l}\text { Zn: } \\
\text { i. ZnO-NPs polymer composites 50:50, 75:25, } \\
\text { 90:10, 98:2, and 100:0 (PU:ZnO wt.\%) } \\
\text { ii. ZnNPs in poly( }(\varepsilon \text { caprolactone) (PCL) matrix }\end{array}$ & $\begin{array}{l}\text { Decreased astroglial cell adhesion and proliferation } \\
\text { Promoted neuroglial cell proliferation }\end{array}$ & {$[99,100]$} \\
\hline \multirow{6}{*}{$\begin{array}{l}\text { Cardiac Tissue } \\
\text { Engineering }\end{array}$} & $\begin{array}{l}\text { PAN: } \\
\text { i. PAN substrate } \\
\text { ii. PAN/PLCL } \\
\text { iii. PAN/CSA } \\
\text { iv. PAN/PLGA }\end{array}$ & $\begin{array}{l}\text { Supporting adhesion and proliferation of } \mathrm{H} 9 \mathrm{c} 2 \\
\text { cardiac myoblasts. } \\
\text { Increasing cell differentiation of } \mathrm{C} 2 \mathrm{C} 12 \text { myoblasts. } \\
\text { In vitro differentiation of hMSC into cardiomyocytes } \\
\text { Integration of cardiomyocytes. }\end{array}$ & [107-109] \\
\hline & $\begin{array}{l}\text { PPy: } \\
\text { i. PPy/Pt } \\
\text { ii. PPy/PC/gelatin }\end{array}$ & $\begin{array}{l}\text { Stimulating cardiac myocytes. } \\
\text { Regeneration of infarct myocardium and cardiac defects. }\end{array}$ & {$[110,111]$} \\
\hline & $\begin{array}{l}\text { CNTs: } \\
\text { i. CNT/PGS/gelatin } \\
\text { ii. CNT/PLA }\end{array}$ & $\begin{array}{l}\text { Supporting for improved alignment of cardiomyocyte } \\
\text { In vitro cardiomyogenesis }\end{array}$ & {$[94,112]$} \\
\hline & $\begin{array}{l}\text { Carbon black: } \\
\text { Liquid crystal elastomers with carbon } \\
\text { black nanoparticles }\end{array}$ & $\begin{array}{l}\text { Enhances cell attachment and viability of } \\
\text { Cardiomyocytes cells. }\end{array}$ & [77] \\
\hline & $\begin{array}{l}\text { Carbon fibers and nanofibers: } \\
\text { Chitosan/carbon nanofibers composite scaffold }\end{array}$ & $\begin{array}{l}\text { Increasing expression of cardiac-specific genes involved } \\
\text { in muscle contraction and electrical coupling. }\end{array}$ & [83] \\
\hline & $\begin{array}{l}\text { Au: } \\
\text { Chitosan/Au (Thermosensitive } \\
\text { conductive hydrogel) }\end{array}$ & $\begin{array}{l}\text { Enhanced cardiomyogenic differentiation and } \\
\text { proliferation of MSCs }\end{array}$ & [94] \\
\hline \multirow{4}{*}{$\begin{array}{l}\text { Bone Tissue } \\
\text { Engineering }\end{array}$} & $\begin{array}{l}\text { PPy: } \\
\text { i. PPy/PLA }\end{array}$ & Stimulating cell growth and proliferation of ADSCs. & [65] \\
\hline & $\begin{array}{l}\text { PAN: } \\
\text { i. PAN/HAP-CS/Gel } \\
\text { ii. PAN/PLA }\end{array}$ & $\begin{array}{l}\text { Improves attachment and proliferation of dental pulp } \\
\text { stem cells. } \\
\text { Enhance bone regeneration }\end{array}$ & {$[113,114]$} \\
\hline & $\begin{array}{l}\text { CNTs: } \\
\text { i. CNT/PCL } \\
\text { ii. CNT/ HAP/PMMA }\end{array}$ & $\begin{array}{l}\text { Enhanced osteogenic signal expression of rat } \\
\text { bone-marrow-derived stroma cells. } \\
\text { Increased mechanical strength of scaffold }\end{array}$ & {$[115,116]$} \\
\hline & $\begin{array}{l}\text { Graphene: } \\
\text { i. Poly-caprolactone (PCL), gelatin and } \\
\text { polyaniline/graphene(PAG) nanoparticles } \\
\text { ii. Polyaniline solution + conductive hydrogel } \\
\text { precursor charged with graphene nanoparticles } \\
\text { iii. Poly(trimethylene carbonate) (PTMC) with } \\
\text { addition of just } 3 \text { wt \% graphene }\end{array}$ & $\begin{array}{l}\text { Mechanical and electrical properties increased and } \\
\text { enhances rat bone marrow-derived mesenchymal stem } \\
\text { cells adhesion and proliferation } \\
\text { Increased elastic modulus and electrical conductivity. } \\
\text { Better supported human osteoblast-like cell adhesion, } \\
\text { proliferation, and morphology comparing } \\
\text { hydrogel alone } \\
\text { Improved tensile strength and electrical conductivity, } \\
\text { enhanced mesenchymal stem cell (MSC) attachment } \\
\text { and proliferation. }\end{array}$ & {$[87,89,91]$} \\
\hline
\end{tabular}

Focusing on neural tissue engineering, where nerve regeneration represents the most thrilling challenge, different approaches were adopted with promising effects demonstrated on cells development. Among conductive polymers, PPy and PEDOT were shown as the most suitable choice, often combined with different kinds of materials. PPy provides from one side excellent mechanical, electrical and stimulus-responsive characteristics, and from the other the highest electrical 
conductivity under biological conditions compared to other conductive polymers. Its great stability and biocompatibility make it the most suitable also for in vivo applications in neural engineering [101-105]. Further, it was shown to enhance cell attachment, differentiation and to improve gene expression level and nerve regeneration. The need to combine PPy with other materials mainly comes from its poor mechanical properties. Thus, while pure PPy is crystalline and brittle, not proper for tissue scaffold materials [117], PPy composite can provide the necessary mechanical properties, while keeping the beneficial conducting and biocompatible properties of PPy. A similar requirement can be highlighted for PEDOT. It possesses better conductivity, thermal stability, electrical, chemical, and environmental stability compared to other conductive polymers, which makes it ideal for providing a continuous stimulation. However, due to its limited processability, it needs to be combined with other kinds of mechanically supporting materials, such as polymers or hydrogels. Thus, it is usually used as coating for fibers of other structures to enhance the conductivity and ensure a proper stimulation to neuronal cells. This was shown to have a positive effect on the development of nerve conduits for axonal regeneration $[105,106]$. Among conductive additives, both gold and carbon were employed in several works due to their biocompatibility and great electrical properties to stimulate neuronal cells, thereby enhancing their proliferation. The use of silver was shown to be limited to its antimicrobial properties, thus to avoid bacteria contamination. Despite very promising results could be obtained from in vitro testing, still several concerns exist about the safety of materials or $A g$ fillers used for conductance due to their lack of degradability, an important issue if aiming to nerve regeneration in vivo. In this picture, an interesting material, which needs to be pointed out is $\mathrm{ZnO}$. In $[99,100]$ zinc nanoparticles were proposed as biodegradable and conductive filler for nerve regeneration, and the resulting effect on the promotion of neuroglial cell proliferation suggest this material as a potential candidate for further future investigations.

Regarding cardiac tissue engineering applications, the highlighted key requirements are related to the elasticity and the possibility to tune the conducting characteristics, in order to effectively reproduce the well-known behavior of excitation-contraction coupling of the heart, thus ensuring the propagation of electrical signals in a synchronized mode. PANI with its unique tunable electrical properties [50-54] and PPy with its ability to be easily combined with other polymers to form a composite material with required mechanical characteristics [40-42] are the most suitable conductive polymers for realizing an engineered tissue that could be suitable for integration with cardiac muscle. With both these materials, an improved adhesion and proliferation of cardiac myoblasts could be observed. Furthermore, supporting the differentiation of these cells into cardiac myocytes, these materials are promising candidates to facilitate the regeneration of cardiac tissue in presence of defects. Interestingly, also nanostructured gold and carbon-based materials were highlighted as extremely promising for improving the regeneration of cardiac defects. Incorporating nanoscale electro-conductive gold nanoparticles into an injectable hydrogel was shown to enhance the properties of myocardial constructs, with extremely powerful potential implication aiming at an injectable smart scaffold [94]. Similarly, nanostructured carbon has been demonstrated as potential strategy to improve the expression of cardiac-specific genes involved in muscle contraction and electrical coupling [83].

Among applications encompassing non-electroactive cells (i.e., bone, cartilage, skin), the most upcoming for conductive biomaterials appear the ones concerning bone tissue engineering. In these, it is essential to provide proper tensile strength, compressive strength and elastic modulus in order to support the physiological loads. In addition to these mechanical properties, proper biomaterials for bone regeneration should be able to reproduce the microstructure of the host tissue, ensuring a proper mineralization of the structure to be integrated in the host environment. Among the conductive polymers, PPy and PANI, used in combination with other materials such as gelatin and PLA, were shown to enhance bone regeneration by supporting and stimulating cell adhesion and proliferation $[65,114,115]$. Despite its limitation in term of mechanical properties, also PEDOT:PSS was used in combination with gelatin and bioactive glass was shown to ensure the possibility to stimulate the construct. These results represent a step forward in combining the tissue engineering 
techniques with the method of enhancing the bone healing and mineralization through an external electrical stimulation.

Up to now, the majority of the applications here discussed were performed only in vitro. One of the major limitations of many of the conductive biomaterials is represented by their non-biodegradability, which restricts their use for in vivo application; this issue is in fact related to the possibility to cause inflammation at implantation site and thence the implant needs surgical removal [118]. Interestingly, to overcome this problem, conductive polymers can be combined with other biodegradable polymers to introduce degradability within the composite and design a conductive biodegradable polymer. Rivers et al. (2002) [119] combined conductive oligomers of pyrrole and thiophene with degradable ester linkages and synthesized conductive biodegradable polymer. In body, these ester linkages can be break down by enzymes and hence resulting in conductive polymer with unique property of biodegradability. Likewise, Shi et al. (2004) [120] also transforms conductive polymers into degradable electroactive polymers by blending them with degradable polymers. Zhang et al. (2010) [27] designed a biodegradable and electrically conductive polymer having aniline pentamer with glycine ethyl ester as side chains and assessed its biological compatibility using Schwann cells. The results confirmed their biocompatibility, as there were no signs of inflammation and cytotoxicity and hence indicating their suitability for scaffold preparation and other biological systems that need electroactivity. Furthermore, a different biodegradable conductive scaffold is prepared in [121] by combination of biodegradable chitosan $(97.5 \%)$ and conductive polypyrrole (PPy, $2.5 \%$ ). Regarding carbon and metal-based fillers, similar concerns can be highlighted. One of the main challenges preventing the translation in vivo of the promising approaches demonstrated in vitro is the systemic response that fillers release might have in the host. These materials might therefore cause an inflammatory and immune response which might affect the integration of the scaffold in the human tissues. The most interesting approaches that have been evaluated to overcome this issue are the fabrication of novel biodegradable materials, such as metal oxides (e.g., $\mathrm{ZnO}$ ) which can provide from one side optimal biocompatibility, non-toxicity and degradability, and from the other great electrical properties.

Summarizing, from a comparison of all the discussed applications, the most relevant part of available literature was addressed to an evaluation of the different conductive biomaterials in term of electrical properties, mechanical properties and of cytocompatibility. Results obtained in terms of conductivity appear promising to adopt these materials for the development of scaffolds which could directly act as a sensing/stimulating element. This would ensure the possibility to interact both with electroactive cells, to monitor or stimulate with a potential based approach, but also with non-electroactive cells, monitoring their development by means of an impedance-based approach. Up to now this kind of approach appears limited to [60] for conductive polymers and to [78] for conductive fillers and currently is not adopted for metal-based fillers. However, the perspective given by these preliminary findings appear stimulating, showing the possibility to correlate quantitative changes of impedance magnitude and phase with cell growth in the scaffold. These approaches might furthermore be combined with the most upcoming strategies in term of impedance-based assays (e.g., impedance tomography) [122]. Integrating the two approaches might give a significant contribute in non-invasive monitoring of 3D cell culture with a significant improvement for field like regenerative medicine and drug development.

\section{Conclusions}

The present systematic review addresses how to design conductive scaffolds to achieve an improved interaction with cell cultures, by focusing on from a biomaterials perspective. Conductive polymers and various nanomaterials and fillers were described and discussed, highlighting their main properties in term of conductivity. The identified characteristics provide these biomaterials an extra edge on other non-conductive materials for scaffold fabrication, as they are capable of measuring 
cellular functions (cell adhesion, proliferation) by means of potential- or impedance-based strategies, along with directing cellular growth via electric stimuli.

Each material was discussed with a focus on the physical properties, possible fabrication techniques and on the most updated clinical applications, including novel uses of these materials for cell monitoring. This non-invasive evaluation of cell behavior by analyzing impedance change caused by cell spreading, adhesion, proliferation etc. represents a huge potential that still have a large space to be investigated. However, nowadays, ongoing researchers are more focused towards transforming a scaffold into a biosensor, which will eliminate a need of any external sensing system. This approach will provide a direct conducting path between cell and scaffold allowing a more effective and sensitive interaction, correlating very precisely even small changes of potential or impedance with specific cellular activities.

Author Contributions: M.A.K., E.C. and S.T. conceived the review structure and wrote the paper; M.S., N.F.L. and E.S. contribute in correcting the initial structure and reviewed the paper.

Funding: This research received no external funding.

Conflicts of Interest: The authors declare no conflict of interest.

\section{References}

1. Edmondson, R.; Broglie, J.J.; Adcock, A.F.; Yang, L. Three-Dimensional Cell Culture Systems and Their Applications in Drug Discovery and Cell-Based Biosensors. Assay Drug Dev. Technol. 2014, 12, $207-218$. [CrossRef] [PubMed]

2. Kujala, V.J.; Jimenez, Z.C.; Väisänen, J.; Tanskanen, J.M.A.; Kerkelä, E.; Hyttinen, J.; Aalto-Setälä, K. Averaging in vitro cardiac field potential recordings obtained with microelectrode arrays. Comput. Methods Programs Biomed. 2011, 104, 199-205. [CrossRef] [PubMed]

3. Qiu, Y.; Liao, R.; Zhang, X. Real-time monitoring primary cardiomyocyte adhesion based on electrochemical impedance spectroscopy and electrical cell-substrate impedance sensing. Anal. Chem. 2008, 80, 990-996. [CrossRef] [PubMed]

4. Rangarajan, S.; Madden, L.; Bursac, N. Use of flow, electrical, and mechanical stimulation to promote engineering of striated muscles. Ann. Biomed. Eng. 2014, 42, 1391-1405. [CrossRef] [PubMed]

5. Gu, W.; Zhao, Y. Cellular electrical impedance spectroscopy: An emerging technology of microscale biosensors. Expert Rev. Med. Devices 2010, 7, 767-779. [CrossRef] [PubMed]

6. Thomas, C.A.; Springer, P.A.; Loeb, G.E.; Berwald-Netter, Y.; Okun, L.M. A miniature microelectrode array to monitor the bioelectric activity of cultured cells. Exp. Cell Res. 1972, 74, 61-66. [CrossRef]

7. Giaever, I.; Keese, C.R. Use of electric fields to monitor the dynamical aspect of cell behavior in tissue culture. IEEE Trans. Biomed. Eng. 1986, 33, 242-247. [CrossRef] [PubMed]

8. Gross, G.W.; Rieske, E.; Kreutzberg, G.W.; Meyer, A. A new fixed-array multi-microelectrode system designed for long-term monitoring of extracellular single unit neuronal activity in vitro. Neurosci. Lett. 1977, 6, 101-105. [CrossRef]

9. Reppel, M.; Pillekamp, F.; Lu, Z.J.; Halbach, M.; Brockmeier, K.; Fleischmann, B.K.; Hescheler, J. Microelectrode arrays: A new tool to measure embryonic heart activity. J. Electrocardiol. 2004, 37, 104-109. [CrossRef] [PubMed]

10. Fendyur, A.; Spira, M.E. Toward on-chip, in-cell recordings from cultured cardiomyocytes by arrays of gold mushroom-shaped microelectrodes. Front. Neuroeng. 2012, 5, 21. [CrossRef] [PubMed]

11. Xu, Y.; Xie, X.; Duan, Y.; Wang, L.; Cheng, Z.; Cheng, J. A review of impedance measurements of whole cells. Biosens. Bioelectron. 2016, 77, 824-836. [CrossRef] [PubMed]

12. Poulton, E.-J. Impedance Measurement in Induced Pluripotent Stem Cell-Derived Cardiomyocytes. In Drug Safety Evaluation; Gautier, J.-C., Ed.; Springer: New York, NY, USA, 2017; pp. 201-209.

13. Szulcek, R.; Bogaard, H.J.; Amerongen, G.P.V.N. Electric Cell-substrate Impedance Sensing for the Quantification of Endothelial Proliferation, Barrier Function, and Motility. J. Vis. Exp. 2014, 51300. [CrossRef] [PubMed]

14. Ramasamy, S.; Bennet, D.; Kim, S. Drug and bioactive molecule screening based on a bioelectrical impedance cell culture platform. Int. J. Nanomed. 2014, 9, 5789-5809. [CrossRef] 
15. Sun, T.; Tsuda, S.; Zauner, K.-P.; Morgan, H. On-chip electrical impedance tomography for imaging biological cells. Biosens. Bioelectron. 2010, 25, 1109-1115. [CrossRef] [PubMed]

16. Wu, H.; Zhou, W.; Yang, Y.; Jia, J.; Bagnaninchi, P. Exploring the Potential of Electrical Impedance Tomography for Tissue Engineering Applications. Materials 2018, 11, 930. [CrossRef] [PubMed]

17. Li, N.; Zhang, Q.; Gao, S.; Song, Q.; Huang, R.; Wang, L.; Liu, L.; Dai, J.; Tang, M.; Cheng, G. Three-dimensional graphene foam as a biocompatible and conductive scaffold for neural stem cells. Sci. Rep. 2013, 3, 1604. [CrossRef] [PubMed]

18. Sain, M.; Ummartyotin, S.; Juntaro, J.; Wu, C.; Manuspiya, H. Deposition of PEDOT: PSS nanoparticles as a conductive microlayer anode in OLEDs device by desktop inkjet printer. J. Nanomater. 2011, 2011, 606714. [CrossRef]

19. Khan, M.A.; Lopomo, N.F.; Serpelloni, M.; Sardini, E.; Sartore, L. Characterization of Sensorized Porous 3D Gelatin/Chitosan Scaffolds via Bio-impedance Spectroscopy. In Sensors, Lecture Notes in Electrical Engineering; Springer: Cham, Switzerland, 2018; Volume 539.

20. Pissis, P.; Kyritsis, A. Electrical conductivity studies in hydrogels. Solid State Ion. 1997, 97, 105-113. [CrossRef]

21. Mawad, D.; Lauto, A.; Wallace, G.G. Conductive Polymer Hydrogels. In Polymeric Hydrogels as Smart Biomaterials; Kalia, S., Ed.; Springer International Publishing: Cham, Switzerland, 2016; pp. 19-44.

22. Balint, R.; Cassidy, N.J.; Cartmell, S.H. Conductive polymers: Towards a smart biomaterial for tissue engineering. Acta Biomater. 2014, 10, 2341-2353. [CrossRef] [PubMed]

23. Choi, W.J.; Jung, J.; Lee, S.; Chung, Y.J.; Yang, C.-S.; Lee, Y.K.; Lee, Y.-S.; Park, J.K.; Ko, H.W.; Lee, J.-O. Effects of substrate conductivity on cell morphogenesis and proliferation using tailored, atomic layer deposition-grown ZnO thin films. Sci. Rep. 2015, 5, 9974. [CrossRef] [PubMed]

24. Ravikumar, K.; Kar, G.P.; Bose, S.; Basu, B. Synergistic effect of polymorphism, substrate conductivity and electric field stimulation towards enhancing muscle cell growth in vitro. RSC Adv. 2016, 6, 10837-10845. [CrossRef]

25. Chronakis, I.S.; Grapenson, S.; Jakob, A. Conductive polypyrrole nanofibers via electrospinning: Electrical and morphological properties. Polymer 2006, 47, 1597-1603. [CrossRef]

26. Skotheim, T.A.; Reynolds, J.R. Handbook of Conducting Polymers, 3rd ed.; CRC Press: Gainesville, FL, USA, 2007.

27. Zhang, Q.; Yan, Y.; Li, S.; Feng, T. The synthesis and characterization of a novel biodegradable and electroactive polyphosphazene for nerve regeneration. Mater. Sci. Eng. C 2010, 30, 160-166. [CrossRef]

28. Bettinger, C.J.; Bruggeman, J.P.; Misra, A.; Borenstein, J.T.; Langer, R. Biocompatibility of biodegradable semiconducting melanin films for nerve tissue engineering. Biomaterials 2009, 30, 3050-3057. [CrossRef] [PubMed]

29. Guimard, N.K.; Gomez, N.; Schmidt, C.E. Conducting polymers in biomedical engineering. Prog. Polym. Sci. 2007, 32, 876-921. [CrossRef]

30. MacDiarmid, A.G. "Synthetic Metals": A Novel Role for Organic Polymers (Nobel Lecture). Angew. Chem. Int. Ed. 2001, 40, 2581-2590. [CrossRef]

31. Heeger, A.J. Semiconducting and Metallic Polymers: The Fourth Generation of Polymeric Materials (Nobel Lecture). Angew. Chem. Int. Ed. 2001, 40, 2591-2611. [CrossRef]

32. Ravichandran, R.; Sundarrajan, S.; Venugopal, J.R.; Mukherjee, S.; Ramakrishna, S. Applications of conducting polymers and their issues in biomedical engineering. J. R. Soc. Interface 2010, 7, S559-S579. [CrossRef] [PubMed]

33. Garner, B.; Georgevich, A.; Hodgson, A.J.; Liu, L.; Wallace, G.G. Polypyrrole-heparin composites as stimulus-responsive substrates for endothelial cell growth. J. Biomed. Mater. Res. 1999, 44, 121-129. [CrossRef]

34. Bousalem, S.; Mangeney, C.; Chehimi, M.M.; Basinska, T.; Miksa, B.; Slomkowski, S. Synthesis, characterization and potential biomedical applications of Nsuccinimidyl ester functionalized, polypyrrole-coated polystyrene latex particles. Colloid Polym. Sci. 2004, 282, 1301-1307. [CrossRef]

35. Cetiner, S.; Kalaoglu, F.; Karakas, H.; Sarac, A.S. Electrospun nanofibers of polypyrrole-poly(acrylonitrile co-vinyl acetate). Text. Res. J. 2010, 80, 1784-1792. [CrossRef]

36. Kim, D.H.; Richardson-Burns, S.M.; Hendricks, J.L.; Sequera, C.; Martin, D.C. Effect of immobilized nerve growth factor on conductive polymers: Electrical properties and cellular response. Adv. Funct. Mater. 2007, 17, 79-86. [CrossRef] 
37. Li, Y.; Neoh, K.G.; Kang, E.T. Plasma protein adsorption and thrombus formation on surface functionalized polypyrrole with and without electrical stimulation. J. Colloid Interfaces Sci. 2004, 275, 488-495. [CrossRef] [PubMed]

38. Akkouch, A.; Shi, G.; Zhang, Z.; Rouabhia, M. Bioactivating electrically conducting polypyrrole with fibronectin and bovine serum albumin. J. Biomed. Mater. Res. A 2010, 92, 221-231. [CrossRef] [PubMed]

39. Ferraz, N.; Strømme, M.; Fellstrom, B.; Pradhan, S.; Nyholm, L.; Mihranyan, A. In vitro and in vivo toxicity of rinsed and aged nanocellulose-Polypyrrole composites. J. Biomed. Mater. Res. A 2012, 100, 2128-2138. [CrossRef] [PubMed]

40. Cui, X.; Hetke, J.E.; Wiler, J.A.; Anderson, D.J.; Martin, D.C. Electrochemical deposition and characterization of conducting polymer polypyrole/PSS on multichannel neural probes. Sens. Actuator A Phys. 2001, 93, 8-18. [CrossRef]

41. Gomez, N.; Schmidt, C.E. Nerve growth factor-immobilized polypyrrole: Bioactive electrically conducting polymer for enhanced neurite extension. J. Biomed. Mater. Res. A 2007, 81, 135-149. [CrossRef] [PubMed]

42. Song, H.K.; Toste, B.; Ahmann, K.; Hoffman-Kim, D.; Palmore, G.T.R. Micropatterns of positive guidance cues anchored to polypyrrole doped with polyglutamic acid: A new platform for characterizie neurite extension in complex environments. Biomaterials 2006, 27, 473-484. [CrossRef] [PubMed]

43. Garner, B.; Hodgson, A.J.; Wallace, G.G.; Underwood, P.A. Human endothelial cell attachment to and growth on polypyrrole-heparin is fibronectin dependent. J. Mater. Sci. Mater. Med. 1999, 10, 19-27. [CrossRef] [PubMed]

44. Gomez, N.; Lee, J.Y.; Nickels, J.D.; Schmidt, C.E. Micropatterned polypyrrole: A combination of electrical and topographical characteristics for the stimulation of cells. Adv. Funct. Mater. 2007, 17, 1645-1653. [CrossRef] [PubMed]

45. Castano, H.; O’Rear, E.A.; McFetridge, P.S. Polypyrrole thin films formed by admicellar polymerization support the osteogenic differentiation of mesenchymal stem cells. Macromol. Biosci. 2004, 4, 785-794. [CrossRef] [PubMed]

46. Evans, G.R. Peripheral nerve injury: A review and approach to tissue engineered constructs. Anat. Rec. 2001, 263, 396-404. [CrossRef] [PubMed]

47. Ateh, D.D.; Navsaria, H.A.; Vadgama, P. Review: Polypyrrole-based conducting polymers and interactions with biological tissues. J. R. Soc. Interface 2006, 3, 741-752. [CrossRef] [PubMed]

48. Ghasemi-Mobarakeh, L.; Prabhakaran, M.P.; Morshed, M.; Nasr-Esfahani, M.H.; Baharvand, H.; Kiani, S.; Al-Deyab, S.S.; Ramakrishna, S. Application of conductive polymers, scaffolds and electrical stimulation for nerve tissue engineering. J. Tissue Eng. Regen. Med. 2011, 5, e17-e35. [CrossRef] [PubMed]

49. Zhou, D.D.; Cui, X.T.; Hines, A.; Greenberg, R.J. Conducting polymers in neural stimulation applications. In Implantable Neural Prostheses; Zhou, D.D., Greenbaum, E., Eds.; Springer: Berlin, Germany, 2010; Volume 2, pp. 217-252.

50. Cullen, D.K.; Patel, A.R.; Doorish, J.F.; Smith, D.H.; Pfister, B.J. Developing a tissueengineered neural-electrical relay using encapsulated neuronal constructs on conducting polymer fibers. J. Neural Eng. 2008, 5, 374-384. [CrossRef] [PubMed]

51. Borriello, A.; Guarino, V.; Schiavo, L.; Alvarez-Perez, M.A.; Ambrosio, L. Optimizing PANi doped electroactive substrates as patches for the regeneration of cardiac muscle. J. Mater. Sci. Mater. Med. 2011, 22, 1053-1062. [CrossRef] [PubMed]

52. Guo, Y.; Li, M.; Mylonakis, A.; Han, J.; MacDiarmid, A.G.; Chen, X.; Lelkes, P.I.; Wei, Y. Electroactive oligoaniline-containing self-assembled monolayers for tissue engineering applications. Biomacromolecules 2007, 8, 3025-3034. [CrossRef] [PubMed]

53. Prabhakaran, M.P.; Ghasemi-Mobarakeh, L.; Jin, G.; Ramakrishna, S. Electrospun conducting polymer nanofibers and electrical stimulation of nerve stem cells. J. Biosci. Bioeng. 2011, 112, 501-507. [CrossRef] [PubMed]

54. Yu, Q.Z.; Shi, M.M.; Deng, M.; Wang, M.; Chen, H.Z. Morphology and conductivity of polyaniline sub-micron fibers prepared by electrospinning. Mater. Sci. Eng. B Solid 2008, 150, 70-76. [CrossRef]

55. Mattioli-Belmonte, M.; Giavaresi, G.; Biagini, G.; Virgili, L.; Giacomini, M.; Fini, M.; Giantomassi, F.; Natali, D.; Torricelli, P.; Giardino, R. Tailoring biomaterial compatibility: In vivo tissue response versus in vitro cell behavior. Int. J. Artif. Organs 2003, 26, 1077-1085. [CrossRef] [PubMed] 
56. Peramo, A.; Urbanchek, M.G.; Spanninga, S.A.; Povlich, L.K.; Cederna, P.; Martin, D.C. In situ polymerization of a conductive polymer in acellular muscle tissue constructs. Tissue Eng. Part A 2008, 14, 423-432. [CrossRef] [PubMed]

57. Luo, S.C.; Mohamed Ali, E.; Tansil, N.C.; Yu, H.H.; Gao, S.; Kantchev, E.A.; Ying, J.Y. Poly(3,4-ethylenedioxythiophene) (PEDOT) nanobiointerfaces: Thin, ultrasmooth, and functionalized PEDOT films with in vitro and in vivo biocompatibility. Langmuir 2008, 24, 8071-8077. [CrossRef] [PubMed]

58. Asplund, M.; Thaning, E.; Lundberg, J.; Sandberg-Nordqvist, A.C.; Kostyszyn, B.; Inganäs, O.; von Holst, H. Toxicity evaluation of PEDOT/biomolecular composites intended for neural communication electrodes. Biomed. Mater. 2009, 4, 1-12. [CrossRef] [PubMed]

59. Karimullah, A.; Cumming, R.S.; Riehle, M.; Gadegaard, N. Development of a Conducting Polymer Cell Impedance Sensor. Sens. Actuators B 2013, 176, 667-674. [CrossRef]

60. Del Agua, I.; Mantione, D.; Marina, S.; Pitsalidis, C.; Ferro, M.; Sanchez-Sanchez, A.; Owens, R.M.; Malliaras, G.G.; Mecerreyes, D. Conducting Polymer Scaffolds based on PEDOT and Xanthan Gum for live-cell Monitoring. ACS Omega 2018, 3, 7424-7431. [CrossRef] [PubMed]

61. Atanasov, V.; Knorr, N.; Duran, R.S.; Ingebrandt, S.; Offenhausser, A.; Knoll, W.; Köper, I. Membrane on a Chip: A Functional Tethered Lipid Bilayer Membrane on Silicon Oxide Surfaces. Biophys. J. 2005, 89, 1780-1788. [CrossRef] [PubMed]

62. Dai, L. Conducting polymers. In Intelligent Macromolecules for Smart Devices: From Materials Synthesis to Device Applications; Dai, L., Ed.; Springer: London, UK, 2004; pp. 41-80.

63. Zhou, J.F.; Wang, Y.G.; Cheng, L.; Wu, Z.; Sun, X.D.; Peng, J. Preparation of polypyrrole-embedded electrospun poly(lactic acid) nanofibrous scaffolds for nerve tissue engineering. Neural Regen. Res. 2016, 11, 1644-1652. [PubMed]

64. Liu, X.; Chen, J.; Gilmore, K.J.; Higgins, M.J.; Liu, Y.; Wallace, G.G. Guidance of neurite outgrowth on aligned electrospun polypyrrole/poly-(styrene- $\beta$-isobutylene- $\beta$-styrene) fiber platforms. J. Biomed. Mater. Res. A 2010, 94, 1004-1011. [CrossRef] [PubMed]

65. Pelto, J.; Björninen, M.; Pälli, A.; Talvitie, E.; Hyttinen, J.; Mannerström, B.; Suuronen Seppanen, R.; Kellomäki, M.; Miettinen, S.; Haimi, S. Novel polypyrrole-coated polylactide scaffolds enhance adipose stem cell proliferation and early osteogenic differentiation. Tissue Eng. Part A 2013, 19, 882-892. [CrossRef] [PubMed]

66. Yu, Q.Z.; Xu, S.L.; Zhang, K.H.; Shan, Y.M. Multi-porous electroactive poly(L-lactic acid)/polypyrrole composite micro/nano fibrous scaffolds promote neurite outgrowth in PC12 cells. Neural Regen. Res. 2013, 8, 31-38. [PubMed]

67. Sudwilai, T.; Ng, J.J.; Boonkrai, C.; Israsena, N.; Chuangchote, S.; Supaphol, P. Polypyrrole-coated electrospun poly(lactic acid) fibrous scaffold: Effects of coating on electrical conductivity and neural cell growth. J. Biomater. Sci. Polym. Ed. 2014, 25, 1240-1252. [CrossRef] [PubMed]

68. Ufere, S.K.J.; Sultana, N. Fabrication and characterization of pcl/ha/ppy composite scaffold using freeze-drying technique. J. Teknol. 2016, 78, 89-94.

69. Sharma, Y.; Tiwari, A.; Hattori, S.; Terada, D.; Sharma, A.K.; Ramalingam, M.; Kobayashi, H. Fabrication of conducting electrospun nanofibers scaffold for three-dimensional cells culture. Int. J. Biol. Macromol. 2012, 51, 627-631. [CrossRef] [PubMed]

70. Jeong, S.I.; Jun, I.D.; Choi, M.J.; Nho, Y.C.; Lee, Y.M.; Shin, H. Development of Electroactive and Elastic Nanofibers That Contain Polyaniline and Poly (L-Lactide-Co-e-Caprolactone) for the Control of Cell Adhesion. Macromol. Biosci. 2008, 8, 627-637. [CrossRef] [PubMed]

71. Iandolo, D.; Ravichandran, A.; Liu, X.; Wen, F.; Chan, J.K.Y.; Berggren, M.; Teoh, S.H.; Simon, D.T. Development and characterization of organic electronic scaffolds for bone tissue engineering. Adv. Healthc. Mater. 2016, 5, 1505-1512. [CrossRef] [PubMed]

72. Mahmoudinezhad, M.H.; Karkhaneh, A.; Jadidi, K. Effect of PEDOT:PSS in tissue engineering composite scaffold on improvement and maintenance of endothelial cell function. J. Biosci. 2018, 43, 307-319. [CrossRef] [PubMed]

73. Jin, G.; Li, K. The electrically conductive scaffold as the skeleton of stem cell niche in regenerative medicine. Mater. Sci. Eng. C 2014, 45, 671-681. [CrossRef] [PubMed]

74. Huang, J.C. Carbon black filled conducting polymers and polymer blends. Adv. Polym. Technol. 2002, 21, 299-313. [CrossRef] 
75. Zois, H.; Apekis, L.; Mamunya, Y.P. Dielectric properties and morphology of polymer composites filled with dispersed iron. J. Appl. Polym. Sci. 2003, 88, 3013-3020. [CrossRef]

76. Tanasa, F.; Zanoaga, M.; Mamunya, Y. Conductive Thermoplastic Polymer Nanocomposites with Ultralow Percolation Threshold; Scientific Research \& Education in the Air Force-AFASES: Brasov, Slovak Republic, 2014; Volume 2.

77. Kim, H.; Zhu, B.; Chen, H.; Adetiba, O.; Agrawal, A.; Ajayan, P.; Jacot, J.G.; Verduzco, R. Preparation of Monodomain Liquid Crystal Elastomers and Liquid Crystal Elastomer Nanocomposites. J. Vis. Exp. 2016, 53688. [CrossRef] [PubMed]

78. Whulanza, Y.; Ucciferri, N.; Domenici, C.; Vozzi, G.; Ahluwalia, A. Biosensors and Bioelectronics Sensing scaffolds to monitor cellular activity using impedance measurements. Biosens. Bioelectron. 2011, 26, 3303-3308. [CrossRef] [PubMed]

79. Wang, S.F.; Shen, L.; Zhang, W.D.; Tong, Y.J. Preparation and Mechanical Properties of Chitosan/Carbon Nanotubes Composites. Biomacromolecules 2005, 6, 3067-3072. [CrossRef] [PubMed]

80. Whulanza, Y.; Battini, E.; Vannozzi, L.; Vomero, M.; Ahluwalia, A.; Vozzi, G. Electrical and mechanical characterisation of single wall carbon nanotubes based composites for Tissue engineering applications. J. Nanosci. Nanotechnol. 2013, 13, 188-197. [CrossRef] [PubMed]

81. Kim, J.H.; Kataoka, M.; Jung, Y.C.; Ko, Y.I.; Fujisawa, K.; Hayashi, T.; Kim, Y.A.; Endo, M. Mechanically Tough, Electrically Conductive Polyethylene Oxide Nanofiber Web Incorporating DNA-Wrapped Double-Walled Carbon Nanotubes. ACS Appl. Mater. Interfaces 2013, 5, 4150-4154. [CrossRef] [PubMed]

82. Behan, B.L.; DeWitt, D.G.; Bogdanowicz, D.R.; Koppes, A.N.; Bale, S.S.; Thompson, D.M. Single-walled carbon nanotubes alter Schwann cell behavior differentially within 2D and 3D environments. J. Biomed. Mater. Res. Part A 2010, 96, 46-57. [CrossRef] [PubMed]

83. Martins, A.M.; Eng, G.; Caridade, G.; Mano, F.; Reis, R.L. Electrically Conductive Chitosan/Carbon Scaffolds for Cardiac Tissue Engineering. Biomacromolecules 2014, 15, 635-643. [CrossRef] [PubMed]

84. Chen, X.; Wu, Y.; Ranjan, V.D.; Zhang, Y. Three-dimensional electrical conductive scaffold from biomaterial-based carbon micro fiber sponge with bioinspired coating for cell proliferation and differentiation. Carbon 2018, 134, 174-182. [CrossRef]

85. Baniasadi, H.; SA, A.R.; Mashayekhan, S.; Ghaderinezhad, F. Preparation of conductive polyaniline/graphene nanocomposites via in situ emulsion polymerization and product characterization. Synth. Met. 2014, 196, 199-205. [CrossRef]

86. Javed, K.; Krumme, A.; Viirsalu, M.; Krasnou, I.; Plamus, T.; Vassiljeva, V.; Tarasova, E.; Savest, N.; Mere, A.; Mikli, V.; et al. A method for producing conductive graphene biopolymer nano fibrous fabrics by exploitation of an ionic liquid dispersant in electrospinning. Carbon 2018, 140, 148-156. [CrossRef]

87. Sayyar, S.; Bjorninen, M.; Haimi, S.; Miettinen, S.; Gilmore, K.; Grijpma, D.; Wallace, G. UV Cross-Linkable Graphene/Poly(trimethylene Carbonate) Composites for 3D Printing of Electrically Conductive Scaffolds. ACS Appl. Mater. Interfaces 2016, 8, 31916-31925. [CrossRef] [PubMed]

88. Guo, W.; Zhang, X.; Yu, X.; Wang, S.; Qiu, J.; Tang, W.; Li, L.; Liu, H.; Wang, Z.L. Self-Powered Electrical Stimulation for Enhancing Neural Differentiation of Mesenchymal Stem Cells on Graphene-Poly(3,4-ethylenedioxythiophene) Hybrid Microfibers. ACS Nano 2016, 10, 5086-5095. [CrossRef] [PubMed]

89. Boroojeni, F.R.R.; Mashayekhan, S.; Abbaszadeh, H.; Ansarizadeh, M. Conductive Nanofiber Scaffold for Bone Tissue Engineering. In Proceedings of the 2017 24th National and 2nd International Iranian Conference on Biomedical Engineering (ICBME), Tehran, Iran, 30 November-1 December 2017; pp. 1-5.

90. Baniasadi, H.; SA, A.R.; Mashayekhan, S. International Journal of Biological Macromolecules Fabrication and characterization of conductive chitosan/gelatin-based scaffolds for nerve tissue engineering. Int. J. Biol. Macromol. 2015, 74, 360-366. [CrossRef] [PubMed]

91. Sartore, L.; Dey, K.; Agnelli, S.; Bignotti, F.; Lopomo, N.; Khan, M.A.; Barbera, V.; Galimberti, M. Novel nanobiocomposite hydrogels based on gelatin/chitosan and functionalized grapheme. In Proceedings of the 9th International Conference on Times of Polymers and Composites, Ischia, Italy, 17-21 June 2018.

92. McKeon-Fischer, K.D.; Freeman, J.W. Characterization of electrospun poly(L-lactide) and gold nanoparticle composite scaffolds for skeletal muscle tissue engineering. J. Tissue Eng. Regen. Med. 2010, 5, 560-568. [CrossRef] [PubMed] 
93. Ravichandran, R.; Sridhar, R.; Venugopal, J.R.; Sundarrajan, S.; Mukherjee, S.; Ramakrishna, S. Gold Nanoparticle Loaded Hybrid Nanofibers for Cardiogenic Differentiation of Stem Cells for Infarcted Myocardium Regeneration. Macromol. Biosci. 2014, 14, 515-525. [CrossRef] [PubMed]

94. Baei, P.; Jalili-firoozinezhad, S.; Rajabi-zeleti, S.; Tafazzoli-shadpour, M. Electrically conductive gold nanoparticle-chitosan thermosensitive hydrogels for cardiac tissue engineering. Mater. Sci. Eng. C 2016, 63, 131-141. [CrossRef] [PubMed]

95. Baranes, K.; Shevach, M.; Shefi, O.; Dvir, T. Gold Nanoparticle-Decorated Scaffolds Promote Neuronal Differentiation and Maturation. Nano Lett. 2016, 16, 2916-2920. [CrossRef] [PubMed]

96. Eid, K.; Eldesouky, A.; Fahmy, A.; Shahat, A.; Abdelaal, R. Calcium Phosphate Scaffold Loaded with Platinum Nanoparticles for Bone Allograft. Am. J. Biomed. Sci. 1937, 5, 242-249. [CrossRef]

97. Nguyen, H.L.; Jo, Y.; Cha, M.; Cha, Y.; Yoon, D.; Sanandiya, N.; Prajatelistia, E.; Oh, D.; Hwang, D. Mussel-Inspired Anisotropic Nanocellulose and Silver Nanoparticle Composite with Improved Mechanical Properties, Electrical Conductivity and Antibacterial Activity. Polymers 2016, 8, 102. [CrossRef]

98. Wickham, A.; Vagin, M.; Khalaf, H.; Bertazzo, S.; Hodder, P.; Dånmark, S.; Bengtsson, T.; Altimiras, J.; Aili, D. Electroactive biomimetic collagen-silver nanowire composite scaffolds. Nanoscale 2016, 8, 14146-14155. [CrossRef] [PubMed]

99. Webster, T.J. Decreased astroglial cell adhesion and proliferation on zinc oxide nanoparticle polyurethane composites. Int. J. Nanomed. 2008, 3, 523-531. [CrossRef]

100. Sezer, U.A.; Ozturk, K.; Aru, B. Zero valent zinc nanoparticles promote neuroglial cell proliferation: A biodegradable and conductive filler candidate for nerve regeneration. J. Mater. Sci. Mater. Med. 2017, 28, 19. [CrossRef] [PubMed]

101. Xu, H.; Holzwarth, J.M.; Yan, Y.; Xu, P.; Zheng, H.; Yin, Y.; Li, S.; Ma, P.X. Conductive PPY/PDLLA conduit for peripheral nerve regeneration. Biomaterials 2014, 35, 225-235. [CrossRef] [PubMed]

102. Lee, J.Y.; Bashur, C.A.; Milroy, C.A.; Forciniti, L.; Goldstein, A.S.; Schmidt, C.E. Nerve growth factor-immobilized electrically conducting fibrous scaffolds for potential use in neural engineering applications. IEEE Trans. Nanobiosci. 2012, 11, 15-21. [CrossRef] [PubMed]

103. Lee, J.Y.; Bashur, C.A.; Goldstein, A.S.; Schmidt, C.E. Polypyrrole-coated electrospun PLGA nanofibers for neural tissue applications. Biomaterials 2009, 30, 4325-4335. [CrossRef] [PubMed]

104. Runge, M.B.; Dadsetan, M.; Baltrusaitis, J.; Knight, A.M.; Ruesink, T.; Lazcano, E.A.; Lu, L.; Windebank, A.J.; Yaszemski, M.J. The development of electrically conductive polycaprolactone fumarate-polypyrrole composite materials for nerve regeneration. Biomaterials 2010, 31, 5916-5926. [CrossRef] [PubMed]

105. Abidian, M.R.; Daneshvar, E.D.; Egeland, B.M.; Kipke, D.R.; Cederna, P.S.; Urbanchek, M.G. Hybrid conducting polymer-hydrogel conduits for axonal growth and neural tissue engineering. Adv. Healthc. Mater. 2012, 1, 762-767. [CrossRef] [PubMed]

106. Wang, S.; Guan, S.; Wang, J.; Liu, H.; Liu, T.; Ma, X.; Cui, Z. Fabrication and characterization of conductive poly (3, 4-ethylenedioxythiophene) doped with hyaluronic acid/poly (L-lactic acid) composite film for biomedical application. J. Biosci. Bioeng. 2017, 123, 116-125. [CrossRef] [PubMed]

107. Bidez, P.R.; Li, S.; MacDiarmid, A.G.; Venancio, E.C.; Wei, Y.; Lelkes, P.I. Polyaniline, an electroactive polymer, supports adhesion and proliferation of cardiac myoblasts. J. Biomater. Sci. Polym. Ed. 2006, 17, 199-212. [CrossRef] [PubMed]

108. Jun, I.; Jeong, S.; Shin, H. The stimulation of myoblast differentiation by electrically conductive sub-micron fibers. Biomaterials 2009, 30, 2038-2047. [CrossRef] [PubMed]

109. Ku, S.H.; Lee, S.H.; Park, C.B. Synergic effects of nanofiber alignment and electroactivity on myoblast differentiation. Biomaterials 2012, 33, 6098-6104. [CrossRef] [PubMed]

110. Nishizawa, M.; Nozaki, H.; Kaji, H.; Kitazume, T.; Kobayashi, N.; Ishibashi, T.; Abe, T. Electrodeposition of anchored polypyrrole film on microelectrodes and stimulation of cultured cardiac myocytes. Biomaterials 2007, 28, 1480-1485. [CrossRef] [PubMed]

111. Kai, D.; Prabhakaran, M.P.; Jin, G.; Ramakrishna, S. Polypyrrole-contained electrospun conductive nanofibrous membranes for cardiac tissue engineering. J. Biomed. Mater. Res. A 2011, 99, 376-385. [CrossRef] [PubMed]

112. Kharaziha, M.; Shin, S.R.; Nikkhah, M.; Topkaya, S.N.; Masoumi, N.; Annabi, N.; Dokmeci, M.R.; Khademhosseini, A. Tough and flexible CNT-polymeric hybrid scaffolds for engineering cardiac constructs. Biomaterials 2014, 35, 7346-7354. [CrossRef] [PubMed] 
113. Azhar, F.F.; Olad, A.; Salehi, R. Fabrication and characterization of chitosan-gelatin/nanohydroxyapatitepolyaniline composite with potential application in tissue engineering scaffolds. Des. Monomers Polym. 2014, 17, 654-667. [CrossRef]

114. Chen, J.; Yu, M.; Guo, B.; Ma, P.X.; Yin, Z. Conductive nanofibrous composite scaffolds based on in-situ formed polyaniline nanoparticle and polylactide for bone regeneration. J. Colloid Interface Sci. 2018, 514, 517-527. [CrossRef] [PubMed]

115. Pan, L.; Pei, X.; He, R.; Wan, Q.; Wang, J. Multiwall carbon nanotubes/polycaprolactone composites for bone tissue engineering application. Colloids Surf. B 2012, 93, 226-234. [CrossRef] [PubMed]

116. Shokuhfar, T.; Makradi, A.; Titus, E.; Cabral, G.; Ahzi, S.; Sousa, A.C.M.; Belouettar, S.; Gracio, J. Prediction of the mechanical properties of hydroxyapatite/polymethyl methacrylate/carbon nanotubes nanocomposite. J. Nanosci. Nanotechnol. 2008, 8, 4279-4284. [CrossRef] [PubMed]

117. Kotov, N.A.; Winter, J.O.; Clements, I.P.; Jan, E.; Timko, B.P.; Campidelli, S.; Pathak, S.; Mazzatenta, A.; Lieber, C.M.; Prato, M.; et al. Nanomaterials for neural interfaces. Adv. Mater. 2009, 21, 3970-4004. [CrossRef]

118. Huang, L.; Hu, J.; Lang, L.; Wang, X.; Zhang, P.; Jing, X.; Wang, X.; Chen, X.; Lelkes, P.I.; MacDiarmid, A.G.; et al. Synthesis and characterization of electroactive and biodegradable ABA block copolymer of polylactide and aniline pentamer. Biomaterials 2007, 28, 1741-1751. [CrossRef] [PubMed]

119. Rivers, T.J.; Hudson, T.W.; Schmidt, C.E. Synthesis of a novel biodegradable electrically conducting polymer for biomedical applications. Adv. Funct. Mater. 2002, 12, 33-37. [CrossRef]

120. Shi, G.; Rouabhia, M.; Wang, Z.; Dao, L.H.; Zhang, Z. A novel electrically conductive and biodegradable composite made of Polypyrrole nanoparticles and polylactide. Biomaterials 2004, 25, 2477-2488. [CrossRef] [PubMed]

121. Huang, J.; Hu, X.; Lu, L.; Ye, Z.; Zhang, Q.; Luo, Z. Electrical regulation of Schwann cells using conductive polypyrrole/chitosan polymers. J. Biomed. Mater. Res. A 2010, 93, 164-174. [CrossRef] [PubMed]

122. Mermoud, Y.; Felder, M.; Stucki, J.D.; Guenat, O.T. Microimpedance tomography system to monitor cell activity and membrane movements in a breathing lung-onchip. Sens. Actuators B 2018, 225, 3647-3653. [CrossRef] 